\title{
Mycoplasma testudinis, a New Species Isolated from a Tortoise
}

\author{
AURIOL C. HILL \\ Medical Research Council Experimental Embryology and Teratology Unit, Woodmansterne Road, Carshalton, Surrey \\ SM5 4EF, England
}

\begin{abstract}
A mycoplasma isolated from the cloaca of a tortoise was shown to be serologically distinct from 82 recognized Mycoplasma and Acholeplasma species. Three clones obtained from the isolated mycoplasma were examined in detail and proved indistinguishable from each other. One of these strains, $01008^{\mathrm{T}}$ (NCTC 11701), is designated the type strain of a new species, Mycoplasma testudinis.
\end{abstract}

Microorganisms belonging to the family Mycoplasmataceae have been recovered from mammals, birds, plants, and insects (3). There have been no reports of the isolation of this group of organisms from reptiles, probably because reptiles have not previously been examined for mycoplasmas. This paper records the isolation and characterization of mycoplasmas from a tortoise (Testudo graeca) and proposes that these mycoplasmas should be classified as a new Mycoplasma species.

\section{MATERIALS AND METHODS}

Mycoplasma strain. A mycoplasma was isolated from the cloaca of a pet tortoise, but was not recovered from the nasopharynx or conjunctiva. Three colonies were each cloned by filtration of a broth culture through a membrane filter $(220-\mathrm{nm}$ pore size), culture of the filtrate on a solid medium, and transferral of a single colony to another agar plate. The subsequent growth was then inoculated into broth, and the whole procedure was repeated four more times (27). The strain was designated $01008^{\mathrm{T}}$ clones 1,2 , and 3 .

Mycoplasma species. Mycoplasma type strains of 82 Mycoplasma and Acholeplasma spp. were obtained from the National Collection of Type Cultures, Colindale, England, or from H. Atobe, M. F. Barile, J. M. Bradbury, R. J. Fallon, E. A. Freundt, J. T. Heywood, F. T. W. Jordan, D. E. Jasper, H. Kirchoff, R. H. Leach, G. Smith, D. Taylor-Robinson, and J. G. Tully.

Mycoplasma species and type strains used were as follows: $M$. agalactiae $\mathrm{PG}^{\mathrm{T}}, M$. alkalescens $\mathrm{PG} 51^{\mathrm{T}}, M$. alvi, Ilsley ${ }^{\mathrm{T}}, M$. anatis $1340^{\mathrm{T}}, M$. arginini $\mathrm{G} 230^{\mathrm{T}}, M$. arthritidis $\mathrm{PG}^{\mathrm{T}}, M$. bovigenitalium $\mathrm{PG} 11^{\mathrm{T}}, M$. bovirhinis $\mathrm{PG}^{\mathrm{T}}{ }^{\mathrm{T}}, M$. bovis $\mathrm{PG} 45^{\mathrm{T}}, M$. bovoculi $\mathrm{M} 165 / 69^{\mathrm{T}}, M$. buccale $\mathrm{CH}-20247^{\mathrm{T}}$, $M$. californicum ST-6 ${ }^{\mathrm{T}}, M$. canadense $275 \mathrm{C}^{\mathrm{T}}, M$. canis $\mathrm{PG} 14^{\mathrm{T}}, M$. capricolum California kid ${ }^{\mathrm{T}}, M$. caviae $\mathrm{G} 122^{\mathrm{T}}, M$. citelli $\mathrm{RG}-2 \mathrm{C}^{\mathrm{T}}, M$. cloacole $383^{\mathrm{T}}, M$. collis $58 \mathrm{~B}^{\mathrm{T}}, M$. columbinosale $694^{\mathrm{T}}, M$. columbinum MMP1 $1^{\mathrm{T}}, M$. columborale MMP4 ${ }^{\mathrm{T}}, M$. conjunctivae $\mathrm{HRC} \mathrm{M}^{\mathrm{T}}, M$. cricetuli $\mathrm{CH}^{\mathrm{T}}, M$. cynos $\mathrm{H} 831^{\mathrm{T}}, M$. dispar $462 / 2^{\mathrm{T}}, M$. edwardii $\mathrm{PG} 24^{\mathrm{T}}, M$. equigenitalium $\mathrm{T} 37^{\mathrm{T}}, M$. equirhinis $\mathrm{M} 432 / 72^{\mathrm{T}}, M$. fastidiosum $4822^{\mathrm{T}}, M$. faucium $\mathrm{DC} 333^{\mathrm{T}}, M$. feliminutum Ben ${ }^{\mathrm{T}}, M$. felis $\mathrm{CO}^{\mathrm{T}}, M$. fermentans $\mathrm{PG}^{\mathrm{T}} \mathrm{T}^{\mathrm{T}}, M$. flocculare $\mathrm{MS} 42^{\mathrm{T}}, M$. gallinaceum $\mathrm{DO}^{\mathrm{T}}, M$. gallinarum $\mathrm{PG}_{16}{ }^{\mathrm{T}}, M$. gallisepticum $\mathrm{PG} 31^{\mathrm{T}}, M$. gallopavonis $\mathrm{WR} 1^{\mathrm{T}}, M$. gateae $\mathrm{CS}^{\mathrm{T}}, M$. genitalium $\mathrm{G}-37^{\mathrm{T}}, M$. glycophilum $486^{\mathrm{T}}, M$. hominis $\mathrm{PG} 21^{\mathrm{T}}, M$. hyopneumoniae $\mathrm{J}^{\mathrm{T}}, M$. hyorhinis $\mathrm{BTS} 7^{\mathrm{T}}$, $M$. hyosynoviae $\mathrm{S}_{16}{ }^{\mathrm{T}}, M$. iners $\mathrm{PG} 30^{\mathrm{T}}, M$. iowae $695^{\mathrm{T}}, M$. lipofaciens $\mathrm{R}_{171^{\mathrm{T}}}$, M. lipophilum $\mathrm{MaBY}^{\mathrm{T}}, M$. maculosum $\mathrm{PG}^{\mathrm{T}} 5^{\mathrm{T}} M$. meleagridis $17529^{\mathrm{T}}, M$. moatsii $\mathrm{MK} 405^{\mathrm{T}}, M$. molare $\mathrm{H} 542^{\mathrm{T}}, M$. muris R1114 ${ }^{\mathrm{T}}, M$. mustelae $\mathrm{MX} 9^{\mathrm{T}}, M$. mycoides subsp. capri $\mathrm{PG}^{\mathrm{T}}, M$. mycoides subsp. mycoides
$\mathrm{PG}^{\mathrm{T}}, M$. neurolyticum type $\mathrm{A}^{\mathrm{T}}, M$. opalescens $\mathrm{MH} 5498^{\mathrm{T}}$, $M$. orale CH-19299,$M$. ovipneumoniae $\mathrm{Y}^{\mathrm{T}} 8^{\mathrm{T}}, M$. pneumoniae $\mathrm{FH}^{\mathrm{T}}, M$. primatum $\mathrm{HRC} 292^{\mathrm{T}}, M$. pullorum $\mathrm{CKK}^{\mathrm{T}}, M$. pulmonis $\mathrm{PG} 34(\mathrm{Ash})^{\mathrm{T}}, M$. putrefaciens $\mathrm{KS}-1^{\mathrm{T}}, M$. salivarium $\mathrm{PG} 20^{\mathrm{T}}, M$. spumans $\mathrm{PG} 13^{\mathrm{T}}, M$. sualvi Mayfield (clone B) $^{\mathrm{T}}, M$. subdolum $\mathrm{TB}^{\mathrm{T}}, M$. synoviae WVU $1853^{\mathrm{T}}$, and M. verecundum $107^{\mathrm{T}}$.

Acholeplasma species and type strains were as follows: $A$. axanthum $\mathrm{S}_{443^{\mathrm{T}}}, A$. equifetale $\mathrm{N} 93^{\mathrm{T}}, A$. granularum $\mathrm{BTS}^{\mathrm{T}}$, A. hippikon $\mathrm{C}^{\mathrm{T}}$, A. laidlawii $\mathrm{PG}^{\mathrm{T}}$, A. modicum PG49 ${ }^{\mathrm{T}}$, A. morum $72-043^{\mathrm{T}}$, A. oculi $19 \mathrm{~L}^{\mathrm{T}}$, and $A$. parvum $\mathrm{H} 23 \mathrm{M}^{\mathrm{T}}$.

Medium and growth conditions. The culture medium used has been described previously by Taylor-Robinson et al. (29) and Hill (10). The purified agar used in the growth medium was either Ionagar no. 2, (Oxoid Ltd., Basingstoke, England) or Lab M agar (Lab M, London, England). Depending on their biochemical activities, the mycoplasmas were grown in liquid medium containing $1 \%$ glucose $(\mathrm{pH} 7.8)$ or $1 \%$ arginine $(\mathrm{pH} 7.3)$. Agar cultures were incubated at $35^{\circ} \mathrm{C}$ either in a humid chamber or under anaerobic conditions in a GasPak system. Liquid cultures were stored at $-70^{\circ} \mathrm{C}$ in ampoules.

Growth requirements and characteristics. The clones were subcultured onto solid medium and grown for 1 week under both aerobic and GasPak anaerobic conditions at 35, 26, 24, and $4^{\circ} \mathrm{C}$. Inhibition of growth by methylene blue was investigated by adding $0.002 \%$ methylene blue to the basal solid medium. The production of a film was tested by inoculating mycoplasmas into basal medium enriched with $10 \%$ egg yolk emulsion (7). Plates were examined at 3, 7, and 14 days.

Absence of reversion. The clones were subcultured by five passages on or in both solid and liquid media that contained no microbial inhibitors to determine whether the organism reverted to a bacterial form. The clones were also treated with Dienes stain (30).

Morphological studies. Mycoplasma colonies grown on agar were examined after 2, 7, and 14 days of incubation. The colonies were transferred to slides and stained with Giemsa stain $(8,13)$. Liquid cultures were observed under dark-field microscopy, and organisms were stained with Giemsa stain (13). Organisms grown in broth were harvested by centrifugation, and the resulting pellet was fixed in $2 \%$ glutaraldehyde and postfixed in $1 \%$ osmium tetroxide. Thin sections were stained with uranyl acetate and lead citrate and examined by electron microscopy.

Filtration studies. Cultures (after $24 \mathrm{~h}$ of incubation) were diluted 1:10 in liquid medium and then filtered through a series of membrane filters (Millipore Corp., Bedford, Mass.) with pore diameters of $100,220,300,450,650$, and $800 \mathrm{~nm}$. 
The titer of colony-forming units in each filtrate was compared with that of the original 1:10 culture dilution.

Sterol dependence. Single mycoplasma colonies grown on a serum agar plate were subcultured onto a serum-free solid medium supplemented with $0.5 \%$ bovine serum albumin, $0.5 \%$ glucose, and $10 \mu \mathrm{g}$ of palmitic acid per $\mathrm{ml}$ and with cholesterol dissolved in Tween 80 added to give concentrations of $20,10,5$, and $1 \mu \mathrm{g} / \mathrm{ml}$. Plates containing no cholesterol or $20 \%$ horse serum were included. Subsequent colonies were passaged three times on similar plates to ensure that no serum was transferred from the original culture, giving misleading results $(5,6,22,32)$.

The clones were tested indirectly for sterol dependence by a disk inhibition method (9), with disks containing $0.02 \mathrm{ml}$ of either a $1.5 \%$ ethanolic solution of digitonin (Sigma Chemical Co., St. Louis, Mo.) or a $20 \%$ aqueous solution of sodium polyanetholesulfonate (Koch-Light Laboratories Ltd., Colnbrook, England), with disks used dry and wet, respectively. The width of the zone of growth inhibition was measured in millimeters.

Biochemical activity. The clones were examined for carbohydrate metabolism; for hydrolysis of aesculin, arginine, and urea; for reduction of methylene blue, resazurin, tetrazolium, and tellurite; and for phosphatase activity $(1,2$, 14, 26, 31, 33).

Erythrocyte techniques. Hemolytic activity, adsorption, and agglutination of erythrocytes were tested with fowl, guinea pig, human, and sheep cells $(1,15)$.

Polyacrylamide gel electrophoresis. Electrophoresis was carried out as described by Razin and Rottem (21). Centrifuged cell suspensions were dried, and $10 \mathrm{mg}$ of each suspension was dissolved in $1.0 \mathrm{ml}$ of phenol-acetic acidwater $(2: 1: 0.5, \mathrm{vol} / \mathrm{vol} / \mathrm{vol})$. To the gels were added 0.025 and $0.05-\mathrm{ml}$ portions of the cell sample. Electrophoresis was carried out at room temperature for $3.5 \mathrm{~h}$ at a constant current of $5 \mathrm{~mA}$ per tube, and the gels were then stained with $1 \%$ naphthol blue black.

DNA base composition. Deoxyribonucleic acids (DNAs) were extracted by the method of Kirby (12), and the guanineplus-cytosine contents were determined from their thermal denaturation temperatures (16). DNAs extracted from Clostridium perfringens and Mycoplasma gallisepticum with known guanine-plus-cytosine content were included as controls.

Serological studies. Antisera were prepared as described previously by Morton and Roberts (17) and Hill (10). The following three tests were used: growth inhibition (4), metabolism inhibition $(11,19,20,28)$, and immunoperoxidase on colonies grown on agar (18). All tests were carried out in duplicate. Two clones were reacted with antisera prepared against the species listed in Materials and Methods. Antisera to the clones were tested with the named Mycoplasma and Acholeplasma species with the exception of A. florum. Antisera to the clones were reacted with each other to demonstrate their relationships. Strain $01008^{\mathrm{T}}$ was reacted with antisera (received from I. M. Robinson) to the type strains of Anaeroplasma bactoclasticum (strain JR [23]) and A. abactoclasticum (strain 6-1 [24]) and to strains 7LA and 161 , representative of serovars 2 and 4 , respectively (25), in the growth and metabolism inhibition and immunoperoxidase tests.

\section{RESULTS AND DISCUSSION}

Colonies of strain $01008^{\mathrm{T}}$ clones 1 and 2 were visible on subculture after 2 days of incubation under anaerobic conditions. No growth was visible aerobically even after pro-

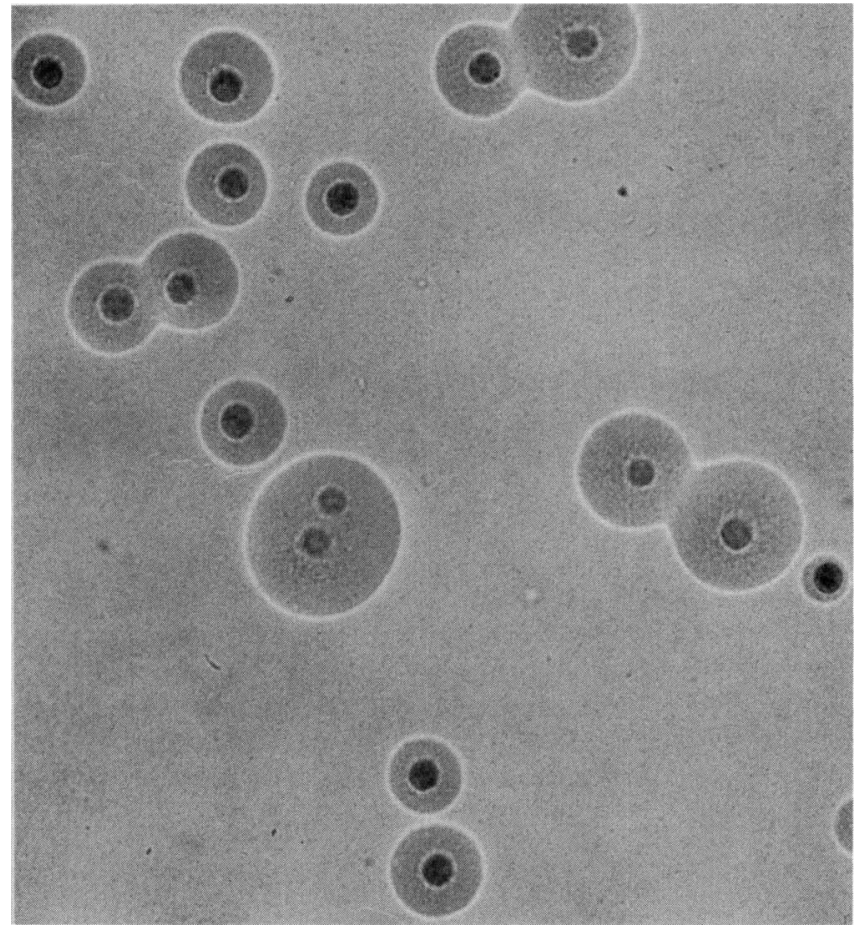

FIG. 1. Colonies of Mycoplasma sp. strain $01008^{\mathrm{T}}$ grown anaerobically for 5 days on an agar medium. $\times 67$.

longed incubation and many passages. The mycoplasmas grew at 35,26 , and 20 , but not $4^{\circ} \mathrm{C}$. The colonies (Fig. 1) had a typical "fried-egg" appearance. The growth characteristics are shown in Table 1 . Strain $01008^{\mathrm{T}}$ grew well in glucose broth in Bijou bottles incubated aerobically and on microtiter plates, showing that the species is not a strict anaerobe.

No motility was observed under dark-field microscopy, and helical forms were not seen. Liquid cultures of the two clones stained by Giemsa stain showed pleomorphic forms characteristic of mycoplasmas. Clone 1 was typical of mycoplasmas also when viewed by the electron microscope. Cells were bounded by a single unit membrane and lacked any evidence of cell wall material. The organism appears to possess a polar bleb region similar to some other mycoplasmas, e.g., M. gallisepticum (Fig. 2).

Filtration of clone 1 showed that of $1.2 \times 10^{8}$ colonyforming units per $\mathrm{ml}$ in the original dilution, reduced numbers passed through the 300 -nm-pore-size $\left(7 \times 10^{7}\right.$ colonyforming units per $\mathrm{ml})$ and 220 -nm-pore-size $\left(2.2 \times 10^{5}\right.$ colony-forming units per $\mathrm{ml}$ ) membranes, and no organisms passed through the 100 -nm-pore-size membrane.

Clones 1 and 2 required cholesterol for growth. They could not be cultured on medium without cholesterol but grew and were passaged on medium containing $1 \mu \mathrm{g}$ of cholesterol per $\mathrm{ml}$. They were susceptible to digitonin and sodium polyanetholesulfonate, with zones of growth inhibition of 10 and $3 \mathrm{~mm}$, respectively.

The organisms belong to the genus Mycoplasma because they are not strict anaerobes, are nonhelical, depend upon sterol for growth, and are sensitive to digitonin and sodium polyanetholesulfonate and because urease could not be demonstrated.

Biochemical activities are shown in Table 1. The strains metabolized some carbohydrates, (glucose, maltose, mannitol [weakly], mannose, and sucrose) but did not hydrolyze 


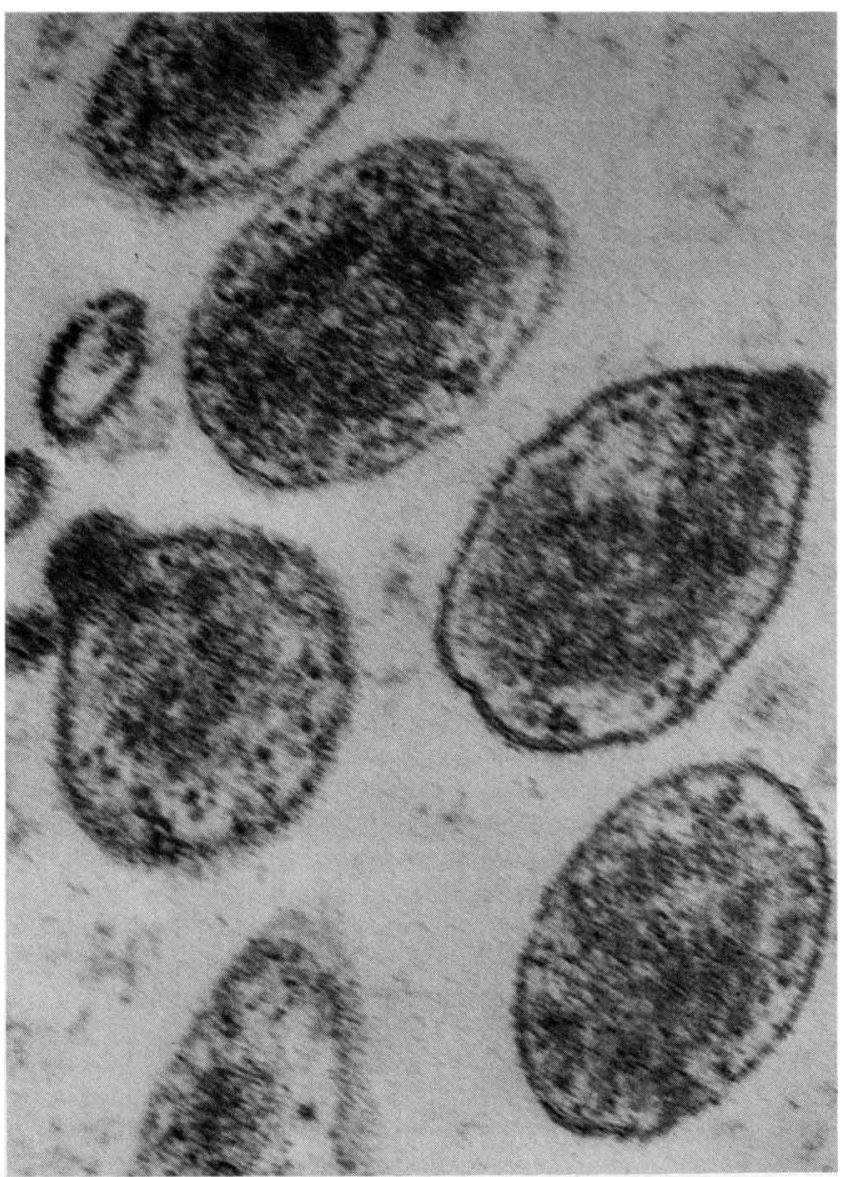

FIG. 2. Electron micrograph of Mycoplasma sp. strain $01008^{\mathrm{T}}$ stained with uranyl acetate and lead citrate. $\times 74,000$.

TABLE 1. Colonial and biochemical characteristics of strain $01008^{\mathrm{T}}$

\begin{tabular}{|c|c|}
\hline Test for: & $\begin{array}{c}\text { Response of } \\
\text { strain } \\
01008^{\mathrm{T}}\end{array}$ \\
\hline \multicolumn{2}{|l|}{ Growth } \\
\hline 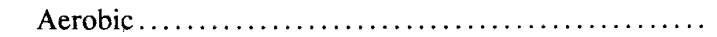 & - \\
\hline 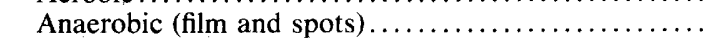 & $+(-)^{a}$ \\
\hline Without serum $\ldots \ldots \ldots \ldots \ldots \ldots \ldots \ldots \ldots \ldots \ldots$ & - \\
\hline Clearing on egg yolk agar $\ldots \ldots \ldots \ldots \ldots \ldots \ldots \ldots \ldots$ & - \\
\hline \multicolumn{2}{|l|}{ Hydroloysis } \\
\hline 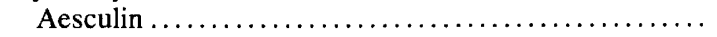 & - \\
\hline 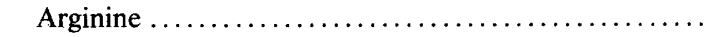 & - \\
\hline Urease production $\ldots \ldots \ldots \ldots \ldots \ldots \ldots \ldots \ldots \ldots$ & - \\
\hline \multicolumn{2}{|l|}{ Fermentation } \\
\hline Glucose.... & + \\
\hline 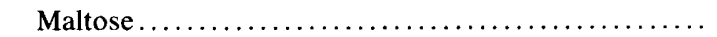 & + \\
\hline 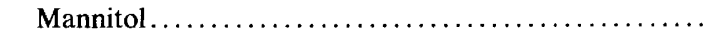 & + \\
\hline 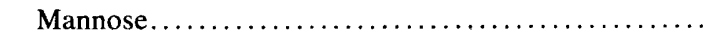 & + \\
\hline 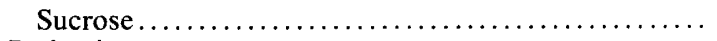 & + \\
\hline \multicolumn{2}{|l|}{ Reduction } \\
\hline 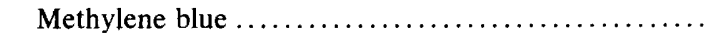 & + \\
\hline 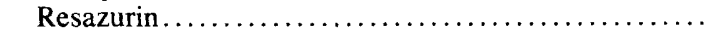 & + \\
\hline 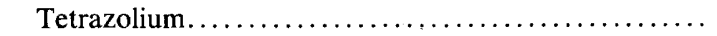 & - \\
\hline Tellurite $\ldots \ldots \ldots \ldots \ldots \ldots \ldots \ldots \ldots \ldots \ldots \ldots \ldots$ & + \\
\hline Casein digestion $\ldots \ldots \ldots \ldots \ldots \ldots \ldots \ldots \ldots \ldots \ldots$ & - \\
\hline Phosphatase production.$\ldots \ldots \ldots \ldots \ldots \ldots \ldots \ldots$ & - \\
\hline
\end{tabular}

${ }^{a}+(-)$, Growth positive, film and spots negative. arginine or ferment arabinose, arbutin, cellobiose, dulcitol, fructose, galactose, glycerol, inositol, lactose, raffinose, rhamnose, salicin, sorbitol, trehalose, or xylose. They lysed but did not adsorb or agglutinate erythrocytes.

The DNA was denatured at a midpoint temperature of $83.5^{\circ} \mathrm{C}$ (corrected for thermal expansion) in several tests. The guanine-plus-cytosine content of $35 \mathrm{~mol} \%$ was determined by the following equation: $T_{m}=69.3+0.41$ (guanineplus-cytosine content), where $T_{m}$ is the thermal denaturation temperature (16). This value is within the known range for Mycoplasma spp.

The three clones gave identical electrophoretic protein patterns. Serological techniques showed identical levels of cross-reaction between the three clones. No cross-reactions were detected with any of the species listed in Materials and Methods (Table 2). Strain $01008^{\mathrm{T}}$ clone 1 showed no crossreaction with Anaeroplasma spp. strains 7LA, 161, and 6-1 ${ }^{\mathrm{T}}$, but it was inhibited by antiserum to $A$. bactoclasticum $\mathrm{JR}^{\mathrm{T}}$ in the growth and metabolism inhibition tests. However, the immunoperoxidase test against antiserum to strain $\mathrm{JR}^{\mathrm{T}}$ was negative. Furthermore, gel diffusion tests carried out by I. M. Robinson with Anaeroplasma sp. strain $\mathrm{JR}^{\mathrm{T}}$ and antiserum to strain $01008^{\mathrm{T}}$ were also negative, indicating that the inhibition shown in the other tests was probably not due to antibody. (A mycoplasma isolated from voles is inhibited in the growth and metabolism inhibition tests by numerous immune and nonimmune sera from several animal species, but immunoperoxidase tests with the same sera are negative [A. Hill, unpublished observations].) Strain $01008^{\mathrm{T}}$ is not a strict anaerobe and will readily grow in the conventional medium used to cultivate Mycoplasma spp. Therefore, strain $01008^{\mathrm{T}}$ cannot be allocated to genus Anaeroplasma, as its growth requirements are distinct from those characteristic of that genus.

Strain $01008^{\mathrm{T}}$ clones 1,2 , and 3 belong to the same species, as they have identical biological characteristics and showed serological and protein pattern identity. As there were no cross-reactions with any other existing named species (see Materials and Methods), strain $01008^{\mathrm{T}}$ clearly represents a new Mycoplasma species. I propose that this species be named Mycoplasma testudinis (testudo, L.n. tortoise; gen. testudinis, of a tortoise) and that the type strain is 01008 (NCTC 11701).

This species, the first mycoplasma isolated from reptiles, is similar in characteristics to the mycoplasmas isolated from mammals and birds. There is no information on the pathogenicity of $M$. testudinis, which was isolated from an apparently healthy animal.

The main characteristics of $M$. testudinis sp. nov. (testudo, L.n. tortoise; gen. testudinis, of a tortoise) are as follows.

Habitat: cloaca of a tortoise

Morphology and physical characteristics: pleomorphic cells bounded by a single unit membrane; colonies on agar

TABLE 2. Serological reactions of the named species ${ }^{a}$ and strain $01008^{\mathrm{T}}$ with antiserum to strain $01008^{\mathrm{T}}$

\begin{tabular}{lccc}
\hline \multirow{2}{*}{ Antigen } & \begin{tabular}{c} 
Growth \\
inhibition \\
\cline { 3 - 4 }$(\mathrm{mm})$
\end{tabular} & $\begin{array}{c}\text { Metabolism } \\
\text { inhibition }\end{array}$ & $\begin{array}{c}\text { Immuno- } \\
\text { peroxidase }\end{array}$ \\
\hline $01008^{\mathrm{T}}$ & 8 & 130,000 & 9,600 \\
All $^{\mathrm{n}}$ other named species $^{a}$ & 0 & $<32$ & $<60$ \\
\hline
\end{tabular}

${ }^{a}$ Named species listed in Materials and Methods. 
with typical "fried-egg" appearance; filterable through 220nm-pore-size membrane; resistant to penicillin

DNA base composition: $35 \% \mathrm{G}+\mathrm{C}$ content

Growth characteristics: microaerophillic; requires sterol for growth and is inhibited by digitonin and sodium polyanetholesulfonate; growth at 20 and 35 , but not $4^{\circ} \mathrm{C}$

Metabolic characteristics: metabolizes glucose and some other carbohydrates; arginine and urea not hydrolized; tetrazolium reduction and phosphatase production negative; film and spots negative

Serological characteristics: distinct from all other Mycoplasma species

Type strain: $01008^{\mathrm{T}}$

\section{ACKNOWLEDGMENTS}

I thank J. Bird and C. Colhoun for the electron micrograph and R. Brooks and I. Whisson for the other photograph.

\section{LITERATURE CITED}

1. Aluotto, B. B., R. G. Wittler, C. O. Williams, and J. E. Faber. 1970. Standardized bacteriologic techniques for the characterization of Mycoplasma species. Int. J. Syst. Bacteriol. 20:35-58.

2. Barber, T. L., and J. Fabricant. 1971. Identification of Mycoplasmatales: characterization procedures. Appl. Microbiol. 21:600-605.

3. Barile, M. F., S. Razin, J. G. Tully, and R. F. Whitcomb. 1979. The mycoplasmas, vol. 2 and 3. Academic Press, Inc., New York.

4. Clyde, W. A., Jr. 1964. Mycoplasma species identification based upon growth inhibition by specific antisera. J. Immunol. 92: $958-965$.

5. Edward, D. G. F. F. 1971. Determination of sterol requirement for Mycoplasmatales. J. Gen. Microbiol. 69:205-210.

6. Edward, D. G. F. F., and W. A. Fitzgerald. 1951. Cholesterol in the growth of organisms of the pleuropneumonia group. J. Gen. Microbiol. 5:576-586.

7. Fabricant, J., and E. A. Freundt. 1967. Importance of extension and standardization of laboratory tests for the identification and classification of mycoplasma. Ann. N.Y. Acad. Sci. 143:50-58.

8. Fallon, R. J., and P. Whittlestone. 1969. Isolation, cultivation and maintenance of mycoplasmas, p. 211-267. In J. R. Norris and D. W. Robbins (ed.), Methods in microbiology, vol. 3B. Academic Press, Inc., New York.

9. Freundt, E. A., B. E. Andrews, H. Erno, M. Kunze, and F. T. Black. 1973. The sensitivity of mycoplasmatales to sodiumpolyanethol sulfonate and digitonin. Zentralbl. Bakteriol. Parasitenkd. Infectionskr. Hyg. Abt.1 Orig. Reihe A 225: 104-112.

10. Hill, A. C. 1971. Mycoplasma caviae, a new species. J. Gen. Microbiol. 65:109-113.

11. Hill, A. C. 1977 . The metabolic inhibition test for mycoplasmas based on phosphatase production. J. Hyg. 79:391-393.

12. Kirby, K. S. 1959. The preparation of deoxyribonucleic acids by the $p$-aminosalicylate-phenol method. Biochim. Biophys. Acta 36:117-124.

13. Klieneberger-Nobel, E. 1962. Morphology of pleuropneumonialike organisms, p. 23-56. In E. Klieneberger-Nobel (ed.), Pleuropneumonia-like organisms (PPLO) Mycoplasmataceae. Academic Press, Inc., New York.

14. Leach, R. H. 1976. The inhibitory effect of arginine on growth of some mycoplasmas. J. Appl. Bacteriol. 41:259-264.

15. Manchee, R. J., and D. Taylor-Robinson. 1968. Haemadsorption and haemagglutination by mycoplasmas. J. Gen. Microbiol. 50:465-478.

16. Marmur, J., and P. Doty. 1962. Determination of the base composition of deoxyribonucleic acid from its thermal denaturation temperature. J. Mol. Biol. 5:109-118.

17. Morton, H. E., and R. J. Roberts. 1967. Production of antimycoplasma (PPLO) antibodies in rabbits. Proc. Soc. Exp. Biol. Med. 125:538-543.

18. Polak-Vogelzang, A. A., R. Hagenaars, and S. Nagel. 1978. Evaluation of an indirect immunoperoxidase test for identification of Acholeplasma and Mycoplasma. J. Gen. Microbiol. 106:241-249.

19. Purcell, R. H., D. Taylor-Robinson, D. C. Wong, and R. M. Chanock. 1966. A color test for the measurement of antibody to the non-acid-forming human mycoplasma species. Am. J. Epidermiol. 84:51-66.

20. Purcell, R. H., D. Taylor-Robinson, D. Wong, and R. M. Chanock. 1966. Color test for the measurement of antibody to T-strain mycoplasmas. J. Bacteriol. 92:6-12.

21. Razin, S., and S. Rottem. 1967. Identification of Mycoplasma and other microorganisms by polyacrylamide-gel electrophoresis of cell proteins. J. Bacteriol. 94:1807-1810.

22. Razin, S., and J. G. Tully. 1970. Cholesterol requirement of mycoplasmas. J. Bacteriol. 102:306-310.

23. Robinson, I. M., and M. J. Allison. 1975. Transfer of Acholeplasma bactoclasticum Robinson and Hungate to the genus Anaeroplasma (Anaeroplasma bactoclasticum [Robinson and Hungate] comb.nov.): emended description of the species. Int. J. Syst. Bacteriol. 25:182-186.

24. Robinson, I. M., M. J. Allison, and P. A. Hartman. 1975. Anaeroplasma abactoclasticum gen.nov., sp.nov.: an obligately anaerobic mycoplasma from the rumen. Int. J. Syst. Bacteriol. 25:173-181.

25. Robinson, I. M., and K. R. Rhoades. 1977. Serological relationships between strains of anaerobic mycoplasmas. Int. J. Syst. Bacteriol. 27:200-203.

26. Shepard, M. C., and D. R. Howard. 1970. Identification of " $T$ ", mycoplasmas in primary agar cultures by means of a direct test for urease. Ann. N.Y. Acad. Sci. 174:809-819.

27. Subcommittee on the Taxonomy of Mycoplasmatales. 1972. Proposal for minimal standards for descriptions of new species of the order Mycoplasmatales. Int. J. Syst. Bacteriol. 22:184-188.

28. Taylor-Robinson, D., R. H. Purcell, D. C. Wong, and R. M. Chanock. 1966. A colour test for the measurement of antibody to certain mycoplasma species based upon the inhibition of acid production. J. Hyg. 64:91-104.

29. Taylor-Robinson, D., M. H. Williams, and D. A. Haig. 1968. The isolation and comparative biological and physical characteristics of T-mycoplasmas of cattle. J. Gen. Microbiol. 54:33-46.

30. Timms, L. 1967. Isolation and identification of avian mycoplasmas. J. Med. Lab. Technol. 24:79-89.

31. Tully, J. G. 1965. Biochemical, morphological and serological characterization of mycoplasma of murine origin. J. Infect. Dis. 115:171-185

32. Tully, J. G., and S. Razin. 1969. Characteristics of a new sterol-nonrequiring mycoplasma. J. Bacteriol. 98:970-978.

33. Williams, C. O., and R. G. Wittler. 1971. Hydrolysis of aesculin and phosphatase production by members of the order Mycoplasmatales which do not require sterol. Int. J. Syst. Bacteriol. 21:73-77. 